\title{
Techno - Resilience for Teachers: Concepts and Action
}

\author{
Failasuf Fadli, Siti Irene Astuti D., Rukiyati Rukiyati \\ Program Pascasarjana Universitas Negeri Yogyakarta, Jalan Colombo No. 1 Yogyakarta, Indonesia
}

\begin{abstract}
The development of global technology is very fast. The invention of new technology penetrated the education sector as well. New technology-based learning media have been widely used by several teachers in various schools in the world. At present, new technological media in learning media such as augmented reality, virtual reality, must be responded to by the teacher. The focus of this research is on the phenomenon of teachers who are slow to respond to new technological developments. These teachers experience stress, anxiety, and give up on using technology-based learning media. Therefore, teacher resilience in responding to contemporary media is very much needed.
\end{abstract}

Keywords - Techno-Resilience, teacher, Teacher Resilience, concept, action

\section{Introduction}

The teacher is an important element in the learning process [1], [2], [3]. The teacher becomes a benchmark of success in the process of transferring knowledge to students [4]. In its performance, the teacher is required to always be perfect at all times, especially when teaching. The teacher when teaching uses learning media. Some learning media use new technology. The rapid development of technology has an impact on the development of learning media.

DOI: 10.18421/TEM92-53

https://doi.org/10.18421/TEM92-53

Corresponding author: Failasuf Fadli, Program Pascasarjana Universitas Negeri Yogyakarta, Jalan Colombo No. 1 Yogyakarta, Indonesia.

Email: failasuffadli.2019@student.uny.ac.id

Received: 27 January 2020.

Revised: 02 May 2020.

Accepted: 09 May 2020.

Published: 27 May 2020.

(c) BY-NC-ND (C) 2020 Failasuf Fadli, Siti Irene Astuti D \& Rukiyati Rukiyati; published by UIKTEN. This work is licensed under the Creative Commons AttributionNonCommercial-NoDerivs 4.0 License.

The article is published with Open Access at www.temjournal.com
The challenges of teacher professionalism in the future will be even greater, technological advances will develop more rapidly.

The development of the world of technology in the last 10 years experienced very rapid progress, especially information technology. The era of the industrial revolution 4.0 in which data sources are collected into a universal unit that can be easily accessed by anyone and at any time. The data sources are then called Big Data. Education was also affected by the development of the 4.0 era. Old learning models are replaced with new learning models. The speed and comfort that humans need now. Learning media alternately adapts to technological developments in the 4.0 era. The flow of technology is directly proportional to the speed of technological change in the world of education. But rapid changes in technology are not comparable to changes in the ability of the teachers to respond to the use of technology in education.

Augmented Reality (AR) is the development of new technologies in the field of education. AR technology in some developed countries such as the United States and the European countries are commonly used. This is based on the results of research [5] which explains that AR technology can enhance teaching and learning which results in critical thinking in formal education. Another emerging technology is Virtual Reality (VR) technology. VR technology is expected to last in the coming decades. With VR technology learning can be done in-depth and can interact virtually with objects, concepts or subject matter. VR technology is suitable for all education circles, ranging from basic education to higher education [6].

In contrast to the developed countries, in the developing countries, the ability of the teachers to use instructional media is still low [7]. Some teachers are still unable to operate computers, elderly teachers who are on average not familiar with the use of computer technology. Moreover, the condition of teachers who teach in remote areas with limited infrastructure [8]. Electricity facilities are still limited, electronic devices are still limited, there is no internet connection. It will greatly affect the ability of teacher skills in operating technology-based learning media. 
Teachers are the most influential component in creating quality educational processes and outcomes [9]. Therefore, all efforts to improve the quality of education are carried out, by supporting teachers to become professional. The task of the teacher is closely related to increasing human resources through the education sector so that efforts are needed to improve the ability of teachers to deliver subject matter [10]. One effort to maintain and improve the quality of teachers is must be able to always exist in a variety of conditions. The teacher must always be ready with various changes and developments in the environment, especially in schools. With the knowledge and knowledge possessed, teachers must be able to overcome problems. The ability of teachers to respond to circumstances to survive as a profession can also be called teacher resilience.

Resilience is a new paradigm in the psychological research. The paradigm that previously focused on the search for the negative side shifted the focus to the search for positive things in an effort to anticipate the negative side. So it can be said of someone's ability to adapt to the risk of problems [11]. In the field of education, teachers often encounter problems both when teaching and outside of academia. When facing problems teachers must be able to find solutions. It takes courage, skills, and confidence to deal with problems [12] so that teachers can respond to bad conditions that have an attitude of resilience. When the teacher encounters a new media, which has never been used, the teacher must try to use it. So the teacher needs a resilience attitude in dealing with the problems of learning media based on contemporary technology.

\section{Research Question}

Era 4.0 is a condition where technology is very close to human life. Teachers as agents of change are required to be always responsive to the development of technology-based learning media. So it needs to be traced to how the teacher's attitude in facing the challenges of resilience using new media. This article will also explore the stages or phases of teacher resilience in dealing with current technology in the teaching and learning process and the final study in this paper will examine what factors support and hinder teachers in being resilient towards current technology-based learning media.

\section{Literateure Review}

\subsection{The concept of Resilience}

Resilience was first formulated by Block \& Kremen with the term Ego-Resiliency which states that resilience is the ability to adjust to the pressure of the situation, both internal and external. In fact, if you want to explore further, the educational figures of Behaviorism are the foundation of the resilience theory [13]. Changes are caused by stimulants that give rise to responsive behavioral relationships based on mechanical kinesthetic abilities. Thorndike said that learning is an interactive activity between stimulus and response [14]. Whereas Gagne said that learning is a stimulus series of responses so that they can understand various physical objects and concepts in responding to their environment [15]. In a macroacademic perspective, resilience can be said to be a learning activity. Resilience is the ability of individuals or communities to adapt to events/situations and conditions that are bad/difficult so that they can deal with the problem well [16]. There are two objects in resilience, the first is the event or can be said to be a stimulus and the second is the attitude to deal with these events or can be said to be a response. Although what is meant in behaviorism theory is a positive stimulus, but in the study of resilience, the stimulus is not only a positive event but can also be a negative/difficult/bad event. This is in line with Skinner's theory which distinguishes the learning reinforcement system into two negative and positive ways as a form of response to the existence of negative and positive events in learning. Therefore, resilience is closely related to the stimulus-response that occurs in humans.

Resilience is a universal idea of people, groups, communities to prevent, minimize and overcome difficulties [17]. This is consistent with the basic assumptions of the theory initiated by Skinner in his work "beyond freedom and dignity" that basically humans have the nature to avoid and find solutions to dangerous events [18]. With the basic ability of humans to survive in situations and conditions, making humans exist in life. In its development, research conducted by Reivich \& Shatte divided resilience skills into 7 abilities, including: (1) Emotion regulation, (2) Impulse control, (3) Optimization, (4) Empathy, (5) Analysis of the cause of the problem, (6) Self-efficacy, and (7) Improvement of aspects positive. Individuals who are resilient can be influenced by several factors [19]. According to Herrman, et al., resilience is influenced by several factors: (1) Personality, (2) Biological, and (3) Environment [20]. Another opinion was stated by Grotberg, that the source of resilience consisted of (1) a source of self strength (2) the ability to do something and (3) the carrying capacity of ownership [17]. 


\section{Result and Discussion}

\subsection{Teacher Resilience}

The teacher is a profession that is very dynamic in carrying out its work. Teachers are required to always change according to the situation, conditions and environment. Although some teachers are late responding to changes in the world of education. However, teachers who give up on change will one day be displaced and replaced by teachers who are able to respond to change well. Results of research conducted by Reed recommends that at the beginning of carrying out his profession, a new teacher, should be given a program or training on how to foster resilience [21]. Schools should be responsible for fostering teacher resilience early in their careers. That was missed in various developing countries. Attention to the beginning of a teacher's career is still weak. Though resilience coaching at the beginning of a career is very useful to anticipate negative events in the future. With basic knowledge about resilience for the teacher, then if the teacher faces a problem, he can find a solution. So that the teacher remains responsible for carrying out their duties, achieving learning objectives and completing their assignments. Resilience skills for teachers need to be developed in every school, both from personal and external factors such as school, family, community and government.

\subsubsection{Psychological Response}

Media is a stimulus and resilience is a response. The first response to teacher resilience is the Psychology response. Psychology is the initial stage of receiving a stimulus in the form of a bad or negative event. There are several psychological responses to resilience, which are the subject of selfregulation. Teachers with various activities carried out sometimes experience stress, depression when dealing with a condition that is not liked. One form of stress faced by a teacher is that when unable to operate a learning media contemporary technology, the teacher will feel nervous or nervous or anxious when handling the media [22], [23]. According to Reivich \& Shatte Emotion regulation is an action where someone remains calm and focused when under a pressure problem [19]. Emotions in themselves can be managed properly. Sadness can be managed into a calm attitude, can get rid of anxiety, and anger. When a teacher discovers media that has never been used and/or cannot operate like new VR technology, then the step that must be taken is to remain calm. In research [24] it is mentioned that emotional regulation can be overcome by tenacious or patient behavior. Tenacious behavior can be applied by a teacher in understanding the existence of learning media that have not been able to operate, in the sense of being patient to learn the new media.

The second is the Impulse control. The ability to control desires, impulses, likes, and pressures that arise from within a person. Individuals with low impulse control often experience rapid emotional changes that tend to control their behavior and thoughts. Such individuals often lose patience, are easily angry, impulsive, and act aggressively in minor situations that are not too important, so that the surrounding social environment feels uncomfortable which results in the emergence of problems in social relationships. The third is Optimism. Where a resilience individual is an optimistic individual. They have hope for the future and believe that they can control the direction of their lives. In a research conducted by Brouskeli et al., when compared to pessimistic individuals, optimistic individuals are more physically fit and are not prone to depression, are better at school, are more productive at work, and win more at sports championships [25]. Optimism implies that the individual believes that he can handle problems that arise in the future.

The fourth psychology response is Empathy. Individuals are able to read psychology signs and emotions from others. Empathy reflects how well individuals recognize the psychological state and the emotional needs of the others. In addition, adding that individuals who empathize are able to listen and understand the others so that they also bring positive reactions from the environment. Someone who has the ability to empathize, tends to have positive social relationships. The fifth response is Self-efficacy. A belief in one's own ability to deal with and solve problems effectively [26]. Self-efficacy also means believing that you are able to succeed. Individuals with high self-efficacy are committed to solving the problem and will not give up when they find that the strategy being used is not working. According to Bandura, individuals who have high self-efficacy will very easily face challenges [27]. Individuals do not feel doubtful because they have full trust in their abilities. This individual according to Bandura will quickly face problems and be able to rise from failures that he experienced [28].

\subsubsection{Critical Thinking Response}

Critical responses in resilience consist of several processes, including understanding and analyzing the causes of problems faced and increasing positive aspects. According to Facione, critical thinking as self-regulation in deciding on something that results in interpretation, analysis, evaluation, and inference, as well as exposure using evidence, concepts, methodologies, criteria, or contextual consideration in which decisions are made [29]. A critical attitude 
is a form of a person's response in dealing with problems. Teachers as educators do not all have the high critical thinking, but at least the existing scientific knowledge can be the basis as a critical response to problems about new technology. Wolcott \& Lynch describe the critical response steps including; Step 1 identifies the problem, relevant information and all allegations about the problem. Step 2, by exploring and identifying existing relationships. Step 3, determine the priorities of existing alternatives and communicate. Step 4, integrate, monitor and refine strategies for overcoming problems. Critical response to resilience can also be interpreted as an ability that includes an increase in positive aspects of life. Individuals who enhance positive aspects of life are able to do these two aspects well, namely: (1) able to distinguish realistic and unrealistic risks, (2) have meaning and purpose in life and are able to see the big picture of life. Individuals who always improve their positive aspects will find it easier to overcome life's problems and play a role in increasing interpersonal skills and emotional control.

\subsubsection{Actualization Response}

Actualization is the desire of someone to use all their abilities to achieve whatever they want. Psychologist Abraham Maslow, in his book "Hierarchy of Needs", uses the term selfactualization as the highest needs and achievements of a human being. Maslow found that regardless of one's ethnic origin, every human being experiences stages of increasing needs or achievements in his own life [30]. Therefore, self-actualization response is the final response as a form of implementing the response to an action that is not liked by someone. In individuals who are resilience, the act of actualization is a response after going through a psychological response and a critical response. The manifestation of teacher resilient in dealing with new technologies is the success of teachers in mastering the procedures for using the media.

\subsection{Resilience Phase}

According to Patterson \& Kelleher, there are four phases in resecting retention: Deteriorating, Adapting, Recovering, and Growing [31]. But in this article, the views are slightly different, providing alternative knowledge about the resilience phase. The initial phase of resilience is a crisis. The crisis phase is more appropriate because it represents the real conditions experienced by someone who is down. Conditions that are threatened by the presence of new technological media make teachers unable to cope with situations. According to Lanceley, personal crises occurs when a person can no longer cope with situations. Crisis conditions have been triggered by mental turmoil, extreme tension and pressure in teachers because they cannot use new technological media. When a teacher who gets information from the principal that the grading system will use an online application system; for teachers who are not accustomed to using the application, the attitude experienced is tense, frightened, feeling burdened with something that cannot be done, can even cause stress, and easily offended because of fatigue [32]. Weak emotions dominate. So, the psychological response is very dominant in this crisis phase. If the psychological response of a person's soul is negative then it cannot be resilience, whereas someone whose psychological response is positive, then that can be the first step to being resilient. For example, optimism and self-efficacy are needed as a basis for resilience. An optimistic attitude encourages us to adapt easily and is strengthened with a strong belief that he will get used to something new he has encountered, in this case, a teacher can confidently learn how to use new technological tools. In the crisis phase, a person experiences mental disequilibrium. One's ego strives to balance internal and external demands on him [33]. The way to balance internal and external demands is to adapt. Literally adapting is a way for an individual or organism to overcome the pressure of the surrounding environment to survive. Organisms that are able to adapt to their environment will be able to respond to changes that occur around them. The teacher begins to adapt to something new. The teacher has begun to gradually try out technological tools or technology-based learning media that have never been used. According to [34] assets and risks contribute independently to resilience or positive adaptability. Risk has a negative effect on the ability to adapt positively, but if the risk is absent, it does not mean that the ability of positive adaptation will be better. The environment and individuals will produce a product called risk. In the view of resilience theory, this is called a risk factor. While assets have a positive effect on positive adaptability, but that does not mean that when assets are absent it will have a negative effect on positive adaptability. This adapting phase if explored more deeply is actually divided into two, physiology adapting and cognitive adapting. Adapting physiology is the adjustment of individuals with something new through the function of the body's organs. A teacher will learn new forms of technology by physically using the device. The use of the five senses is indispensable in adapting physiology. While cognitive adaptation is someone's adaptation using the mind. A person's cognitive abilities include the ability to identify, map, and analyze. Cognitive forms of adapting resilience attitudes of teachers can be in the form of identifying 
the causes of difficulties in using new technology, exploring self-abilities, learning, developing strategies for using new technologies, then analyzing the progress and weaknesses of using new technologies. The third resilience phase is the action phase. After going through a crisis and adapting phase then someone implements their adapting capabilities by using a new medium of technology. In this phase, all problems or obstacles regarding the use of new technology have been overcome. The action phase is the final step in responding to something new. In this phase the level of confidence is high [35]. Individuals are in a normal or neutral condition so that this phase can also be said to be the recovery phase. In this phase, strengthening and enhancing positive aspects are needed. Resilience teachers who are in this position have a calm attitude. The mind is fresh and physically fit where the source is ready to be used for new activities or the use of newly recognized technological tools.

\subsection{Resilience Attitude Factor}

Resilience attitude factors consist of three factors. First, individuals, abilities that arise from within themselves are important factors in carrying out an attitude of resilience [17], which states that the source of resilience comes from the attitude, confidence, and feelings of a person. Resilience can be increased when someone has strengths that come from within themselves such as self-confidence, optimism, respect, and empathy. According to Herrman et al., personality characteristics, selfefficacy, self-esteem, internal locus of control, optimism, intellectual capacity, positive self-concept, demographic factors (age, sex, ethnicity), hope, toughness, emotional regulation, and so on [20]. The second factor is the closest environmental factor. Family, school, peers, secure attachment to mothers, family stability, safe and secure relationships with parents, and social support from peers. This environment is related to the level of resilience. The third factor is the broad environment. Community systems such as a good school environment, community service, opportunities to do sports and arts activities, cultural factors, spirituality, and religion as well as lack of experience related to violence, are related to the level of resilience.

\section{Conclusion}

The final result of this article is to answer three research questions. First, the attitude of teacher resilience in facing the challenges of resilience in terms of delivery of learning in using new media that is with psychological responses, critical responses, and actualization responses. The second conclusion is the stage or phase of teacher resilience in dealing with current technology in the teaching and learning process covering the crisis, adapting and action phases. The conclusions of these three factors or sources of teacher resilience are influenced by three factors; the individual in the teacher which includes aspects of psychology and the ability of individual skills. The second factor is the closest environment and the third factor is the wider environment.

\section{References}

[1]. Hassan, B., Alias, M., Saleh, K. M., \& Awang, H. (2017). Students' perceptions of their teachers' performance in teaching engineering drawing in Nigerian tertiary institutions. Path of Science, 3(10), 3001-3012.

[2]. Bichi, A. A. (2017). Evaluation of Teacher Performance in Schools: Implication for Sustainable Development Goals. Northwest Journal of Educational Studies, 2(1), 103-113.

[3]. Börü, N. (2018). The Factors Affecting TeacherMotivation. International

Instruction, 11(4), 761-776.

[4]. Morgan, G. B., Hodge, K. J., Trepinski, T. M., \& Anderson, L. W. (2014). The stability of teacher performance and effectiveness: Implications for policies concerning teacher evaluation. Education Policy Analysis Archives/Archivos Analíticos de Políticas Educativas, 22, 1-21.

[5]. Saltan, F., \& Arslan, Ö. (2017). The Use of Augmented Reality in Formal Education: A Scoping Review. EURASIA Journal of Mathematics, Science \& Technology Education, 13(2), 503-520.

[6] Martín-Gutiérrez, J., Mora, C. E., Añorbe-Díaz, B., \& González-Marrero, A. (2017). Virtual technologies trends in education. EURASIA Journal of Mathematics Science and Technology Education, 13(2), 469-486.

[7] Alwi, S. (2017). Problematika guru dalam pengembangan media pembelajaran. ITQAN: Jurnal Ilmu-Ilmu Kependidikan, 8(2), 145-167.

[8] Diah A.K, R., \& Pradna. P, P. (2012). Teacher resilience in remote schools. Jurnal Psikologi Pendidikan dan Perkembangan, 1(02), 1-6. 
[9] Schacter, J. (2001). Teacher performance-based accountability: Why, what and how. Milken Family Foundation.

[10] Hasbay, D., \& Altindag, E. (2018). Factors that affect the performance of teachers working in secondary-level. Academy of Educational Leadership Journal, 22(1), 1-19.

[11] Garmezy, N. (1985). Stress-resistant children: The search for protective factors. Recent research in developmental psychopathology, 4, 213-233.

[12] Prihastuti, P. (2013). Educator resilience profile based on resilience quetient test. Jurnal Penelitian dan Evaluasi Pendidikan, 15(2), 199-214.

[13] Block, J., \& Kremen, A. M. (1996). IQ and egoresiliency: conceptual and empirical connections and separateness. Journal of personality and social psychology, 70(2), 349-361.

[14]. Thorndike, E. L. (1913). The psychology of learning (Vol. 2). Teachers College, Columbia University.

[15]. Gagne Robert M. (1970). The conditions of learning. In holt, Rinehart and Winston Inc (2nd ed.).

[16]. Muller, S. M., Gorrow, T. R., \& Fiala, K. A. (2011). Considering Protective Factors as a Tool for Teacher Resiliency. Education, 131(3), 545-555.

[17]. Grotberg, E. (1995). A guide to promoting resilience in children: strengthening the human spirit, Early Childhood Development: Practice and Reflections Number 8. Bernard van Leer Foundation.

[18]. Skinner, B. F. (1973). Beyond freedom and dignity. 1971. New York: Bantam, Vintage Book.

[19] Reivich, K., \& Shatte, A. (2003). The resilience factor: 7 keys to finding your inner strength and overcoming life's hurdles. Harmony.

[20] Herrman, H., Stewart, D. E., Diaz-Granados, N., Berger, E. L., Jackson, B., \& Yuen, T. (2011). What is resilience?. The Canadian Journal of Psychiatry, 56(5), 258-265.

[21] Reed, Y. (2017). Becoming a teacher in Australia: reflections on'the resilience factor'in teacher professional development and teacher retention in the 1940s and at the beginning of the twenty-first century. Journal of Education (University of KwaZulu-Natal), (69), 185-210.

[22] Schussler, D. L., Greenberg, M., DeWeese, A., Rasheed, D., DeMauro, A., Jennings, P. A., \& Brown, J. (2018). Stress and release: Case studies of teacher resilience following a mindfulness-based intervention. American Education, 125(1), 1-28.
[23] Rizqi, M. A. (2017). Stress and resilience among EFL teachers: an interview study of an Indonesian junior high school teacher. TEFLIN Journal, 28(1), 22-37.

[24] Mestre, J. M., Núñez-Lozano, J. M., GómezMolinero, R., Zayas, A., \& Guil, R. (2017). Emotion regulation ability and resilience in a sample of adolescents from a suburban area. Frontiers in psychology, 8, 1980.

[25] Brouskeli, V., Kaltsi, V., \& Loumakou, M. (2018). Resilience and occupational well-being of secondary education teachers in Greece. Issues in Educational Research, 28(1), 43-60.

[26] Razmjoo, S. A., \& Ayoobiyan, H. (2019). On the Relationship between Teacher Resilience and Selfefficacy: The Case of Iranian EFL Teachers. Journal of English Language Teaching and Learning, 11(23), 277-292.

[27] Bandura, A. (1997). Self-efficacy the exercise of control. In W.H Freeman and Company, 1-604.

[28] Bandura, A. (1999). Self-efficacy in changing societies. Cambridge University Press.

[29] Facione, P. A. (1992). Critical thinking: What it is and why it counts. Insight Assessment. California Academic Press, 102.

[30] Maslow, A. H. (1943). A theory of human motivation. Psychological review, 50(4), 370-396.

[31] Patterson, J. \& Kelleher, P. (2005). Resilience school leaders: Stategies for turning adversity into achievement. Alexandria: Association for Supervission and Curriculum Develompent (ASCD).

[32] Poyner, N. B. (2016). Factors that contribute to resilience of early care and education teachers. Walden University Press.

[33] Woolley, N. (1990). Crisis theory: A paradigm of effective intervention with families of critically ill people. Journal of advanced nursing, 15(12), 14021408.

[34] Utami, C. T., \& Helmi, A. F. (2017). Self-efficacy dan resiliensi: Sebuah tinjauan meta-analisis. Buletin Psikologi, 25(1), 54-65.

[35] Ulya, A., \& Ahmad, N. A. (2018). Enhancing Efficacy of Special Education Early Teachers: The External and Psychological Resilience Factors Perspectives. International Journal of Academic Research in Business and Social Sciences, 8(7), 737749. 